\title{
Osaksi elinkeinopolitiikkaa
}

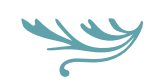

AIK UISK OULUTUKSESTA TULI suhteellisesti suurin leikkauskohde rakennepolitiikassa, vaikka viime vuosikymmenellä se sai jakamattoman poliittisen huomion. Miksi?

Mielestäni sisäinen hajanaisuus teki aikuiskoulutuksesta helpon kohteen. Tämän vuoksi nyt on unohdettava ammattitaidon ja sivistyksen välinen vastakkainasettelu, joka kulminoituu erilaisten oppilaitosten edunvalvontana. Jokaisen aikuiskoulutuksen puolustajan pitää ymmärtää, että eripuraisina olemme heikkoja.

Toiseksi aikuiskoulutuksesta on vaikea saada otetta. Se pitää sisällään lähes kaiken, ja julkinen kuva on aika hähmäinen. Aikuiskoulutus on puuhastelua, rakennemuutoksesta selviämistä, omaa harrastuneisuutta, ammattitaidon kehittämistä, työttömyydenhoitoa ja paljon muuta. Kuva ei hahmotu tuloksia ja sijoitukselle saatavaa tuottoa korostavana aikana.

\section{KOKONAISKUVA KADOKSISSA}

Vuonna 2009 ammatillisesti suuntautuneen aikuiskoulutuksen kokonaisuudistuksen johtoryhmä tasapainoili hallinnonalojen välimaastossa: "Työvoimapoliittinen aikuiskoulutus, omaehtoinen koulutus ja henkilöstökoulutus muodostavat nykyisen aikuiskoulutuksen kokonaisuuden”. Tuosta muotoilusta ei yksilöiden tai yritysten tarpeita tunnista.

Aikuiskoulutuspolitiikka kulminoituu hallintoon. Eri oppilaitosmuodoille ja kohderyhmille on erilaiset hallinnot ja rahoituskanavat, joiden kautta toiminta määritetään. Hallinnollinen ohjaus syrjäyttää helposti asiakkaiden tarpeita. Kokonaiskuvaa ei ole ollut edes valtion budjettikirjassa, jossa aikuiskoulutuksen rahoitus jakautuu usean eri ministeriön alle.
Vaalikaudella 2011-2015 Suomi yritti uudelleen määrittää julkisia palveluita, joihin koulutuskin kuuluu. Kyse on toistaiseksi ollut pyrkimyksestä tiivistää oppilaitosrakenteita ja leikata menoja. Esitykset toisen asteen koulutuksen järjestäjäverkon ja rahoituksen uudistamiseksi osoittautuivat poliittisesti toteuttamiskelvottomiksi eduskuntavaalien alla.

Tarve uudistuksiin ei ole poistunut, sillä Suomi on suuremmissa ongelmissa kuin koskaan aiemmin toisen maailmansodan päättymisen jälkeen. Pieni Suomi nousee vain uudistumalla, eikä mikään yhteiskunnallinen palvelu saisi olla kriittisen arvioinnin ulkopuolella. Palveluiden tuottaminen ei vastaa enää väestön ja työelämän tarpeita eikä sijaintia. Muutoksia tarvitaan, vaikka julkisista menoista ei leikattaisi euroakaan.

Taidamme olla hakoteillä, jos kevään 2015 hallitusohjelmassa kuumimmaksi aikuiskoulutuksen kysymykseksi nousee opetus- ja kulttuuriministeriön sekä työ- ja elinkeinoministeriön välinen työnjako.

\section{OSAAMISVAATIMUKSET MUUTTUVAT}

Reilusti yli vuosikymmen sitten parlamentaarinen aikuiskoulutustyöryhmä asetti tavoitteeksi 1-2 viikon vuotuisen koulutusjakson ja perusteellisen osaamisen uusintamisen $10-15$ vuoden välein kaikille kansalaisille. Tavoite ei toteutunut vaan aikuiskoulutukseen osallistuminen on vähentynyt 2000-luvun alkuvuosien huippuluvuista. Suomalaiset aikuiset kouluttautuvat yhä enemmän kuin ketkään muut, mutta trendi on kääntynyt.

Yksi syy voi olla koulutuksen vaihtuminen oppimiseen. Internet on tuonut tiedon kaikkien ulottuville ennennäkemättömällä tavalla. Samaan aikaan aikuiset ovat entistä paremmin koulutettuja ja he osaa- 
vat hyödyntää erilaisia tiedonlähteitä. Oppilaitokset ovat menettäneet monopolinsa uuteen tietoon. Toinen syy voi olla perinteisen henkilöstökoulutuksen väheneminen, kun osaaminen kehittyy yhä erilaisemmin keinoin. Onko muodollinen aikuiskoulutuksen tarjonta pysynyt mukana kehityksessä?

Suomen talous on ollut pysähdyksissä vuodesta 2008 lähtien, minkä seurauksena maassa on tosiasiallisesti puoli miljoonaa työtöntä. Suomesta puuttuu investointeja. Julkisen talouden näkymät ovat koko ajan heikommat eikä valtio ilmeisesti voi tukea työllisyyden kasvua.

Metsä- ja matkapuhelinteollisuus sekä pankki- ja vakuutusala ovat esimerkkejä voimakkaasti muuttuvista toimialoista, joilta on kadonnut paljon työpaikkoja. Tilalle syntyneen työn vaatimukset eivät useinkaan ole kohdanneet vanhoista työpaikoista työttömäksi jääneiden osaamista. Tämä on luovan lieveilmiö.

Työuran aikana syntynyt hiljainen tieto korvautuu usein korkeammalla muodollisella koulutuksella, koska sitä on työmarkkinoilla saatavissa. Monimutkaistuvassa maailmassa osaamisvaatimukset muuttuvat, jolloin perustutkinnot ammatillisesta tai korkeakoulutuksesta kelpaavat lähinnä pääsylipuiksi työelämään.

\section{TUTKINTO VAIN YKSI OSA AMMATTITAITOA}

Suurin osa aikuisten taidoista on kehittynyt muodollisten opintojen jälkeen työtä tehden. Oppiminen on useimmilla työpaikoilla kuitenkin toissijainen toiminta, sillä se tapahtuu työn tekemisen ohessa ja työn ehdoilla. Oppiminen ja tulosten hyödyntäminen jäävät liian usein yksilön vastuulle, ja koko työyhteisön kehittyminen jää sivuun.

Työuran aikana tulee vastaan myös ongelmia, joihin aiemmat opit eivät anna vastauksia. Niistä selviäminen edellyttää uuden oppimista. Kyse voi olla päivän "kurssituksesta" tai ylemmän korkeakoulututkinnon suorittamisesta. Samalla on tärkeä oppia, mistä tarpeettomaksi käyneestä on mahdollista luopua.

Ammatillinen ja korkeakoulutus ovat rakentuneet tiukasti tutkintojen ympärille. Työuran aikana opitun tunnistamiseen on luotu henkilökohtaistami-
JOUDUMME

TODISTAMAAN

PÄTEVYYTT ̈̈MME JA

OSAAMISTAMME USEAAN

OTTEESEEN TYÖURAN

\section{AIKANA.}

nen näyttötutkintoihin valmistavaan koulutukseen ja tutkintojen suorittamiseen. Korkeakouluissa on käytössä aiemmin hankitun osaamisen tunnustaminen eli ahotointi. Vanhan tunnustaminen ei kuitenkaan anna eväitä, jos työ vaatii jotain aivan uutta.

Vaihtaessamme työpaikkaa joudumme todistamaan pätevyyttämme ja osaamistamme useaan otteeseen työuran aikana. Koulutus- ja tutkintojärjestelmällä on ollut vahva rooli osaamisen kehittämisen lisäksi pätevyyden osoittamisessa. On hyvä muistaa, että työnantajat arvioivat tutkintoja enemmän todellista ammattitaitoa ja osaamista.

\section{TYÖELÄMÄ TARVITSEE AKTIIVISIA KANSALAISIA}

Ammatillisesta aikuiskoulutuksesta löytyy 377 erilaista tutkintoa, jotka muodostuvat noin 3400 tutkinnon osasta. Tämän lisäksi korkeakouluilla on varmasti satoja eri tutkintoja. Muodolliset tutkinnot opetussuunnitelmineen tai perusteineen eivät pysy perässä, kun uudet teknologiat leviävät ja synnyttävät uusia ammatteja. Peliala on tästä hyvä esimerkki.

Ammatit ja työn tekeminen muuttuvat yhä edelleen tulevaisuudessa, ja se vaatii ihmisiltä aivan erilaisia taitoja. Työelämä tarvitsee aktiivisia kansalaisia vain tottelemaan opetettujen koneenkäyttäjien sijaan. Ilman toimeentuloa eivät sivistyksen ja kansalaisuuden kauniit ajatukset toteudu. Ristiriidat näiden asioiden välillä ovat meidän omassa ajattelussamme.

Liittäisin aikuiskoulutuksen suoraan elinkeinopolitiikkaan, jotta sen rahoitus olisi edes jotenkuten turvattu. Näin aikuisten osaamisen kehittäminen liittyisi suoraan Suomen uudistamiseen. Työelämässä tarvittavien taitojen kouluttaminen on parasta syrjäy- 
tymisen ehkäisemistä. Edes rivien välissä en ota kantaa nykyisiin oppilaitosmuotoihin tai oppisisältöihin.

Voisivatko ammatillinen aikuiskoulutus ja korkeakoulut oppia jotain vapaan sivistystyön joustavuudesta? Kyllä, mutta niiden rahoituksen on tehtävä mahdolliseksi epämuodolliset ja yksittäisiin tarpeisiin räätälöitävät osaamiskokonaisuudet. Koulutustar-

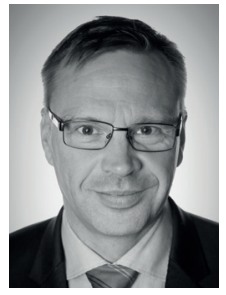

Petri Lempinen

FT, toimitusjohtaja

Ammattiosaamisen

kehittämisyhdistys AMKE ry

jonnan suunnittelun sijaan tarvitsemme asiakastutkimuksia ja tarpeiden kartoittamista.

\section{TAUSTA-AINEISTO}

Kangasniemi, J. \& Lempinen, P. (2009).

Aikuiskoulutuksen uusi maasto 2010-luvulla.

Teoksessa Varjonen, B. \& Maijala, H. (toim).

Ylempi ammattikorkeakoulututkinto - osana

innovaatioympäristöjä, 49-61.

Lempinen, P. (2014). Työelämä muuttuu, entä koulutus? Ammattikasvatuksen aikakauskirja 16(2), 74-81.

Lempinen, P. (2015). Pelkkä oman alan osaaminen ei enää riitä. Työpoliittinen aikakauskirja 1/2015, 17-26.

OPM (2002). Parlamentaarisen aikuiskoulutustyöryhmän mietintö. Opetusministeriön työryhmien muistioita 2002:3. Yliopistopaino Helsinki.

OKM (2009). Ammatillisesti suuntautuneen aikuiskoulutuksen kokonaisuudistus. AKKUjohtoryhmän toimenpide-ehdotukset Itoinen väliraportti). Opetusministeriön työryhmämuistioita ja selvityksiä 2009:11. Yliopistopaino Helsinki. 